\begin{tabular}{|c|c|c|}
\hline & Int.J.Curr.Microbiol.App.Sci (2021) 10(12): 43-53 & \\
\hline & $\begin{array}{l}\text { International Journal of Current Microbiology and Applied Sciences } \\
\text { ISSN: 2319-7706 Volume } 10 \text { Number } 12 \text { (2021) } \\
\text { Journal homepage: http://www.iicmas.com }\end{array}$ & $\$ 0$ \\
\hline $\begin{array}{l}\text { EXCELLENT } \\
\text { PUBLISHERS }\end{array}$ & & \\
\hline
\end{tabular}

\title{
Performance and Yield Gap Analysis of Groundnut (Arachis hypogaea L.), Var Dharani through Cluster Front Line Demonstration in South Eastern Ghat Zone of Odisha
}

\author{
S. R. Dash ${ }^{1}$, S. P. Sangramsingh ${ }^{2}$, B. K. Routray ${ }^{3}$, A. K. Rai ${ }^{1}$ and H. Das ${ }^{4}$ \\ ${ }^{1}$ Krishi Vigyan Kendra, Malkangiri, OUAT, Bhubaneswar, Odisha, India \\ ${ }^{2}$ Joint Director Extension, Directorate of Extension, OUAT, Bhubaneswar, Odisha, India \\ ${ }^{3}$ Krishi Vigyan Kendra, Jajpur, OUAT, Bhubaneswar, Odisha, India \\ ${ }^{4}$ RRTTSS, Kalimela, OUAT, Bhubaneswar, Odisha, India \\ *Corresponding author
}

\section{Keywords \\ Yield gap, \\ Technology gap, \\ Extension gap, \\ Technological \\ index, Benefit Cost ratio}

Article Info

Received:

06 November 2021

Accepted:

28 November 2021

Available Online:

10 December 2021
The present study was conducted during rabi season 2019-20 in Khairiput and Malkangiri blocks of Malkangiri district, comprising eighty four number of farmers from four adopted villages of Krishi Vigyan Kendra, Malkangiri, in South Eastern Ghat Zone of Odisha. Farmers participatory field trials on Ground nut Var Dharani were conducted on cluster basis at for villages MV-3, MV-9, and MV-8 of Malkangiri block and Dhusuriguda of Khairiput block of Malkangiri district, in South Eastern Ghat Zone of Odisha. Observation on growth and yield parameters were taken and economic analysis was done. The final seed yield was recorded at the time of harvest and the gross return in (Rs $\mathrm{ha}^{-1}$ ) was calculated based on prevailing market prices. The results from the demonstration conclusively proved that ground nut variety Dharani recorded the higher yield (21.6 q ha ${ }^{-1}$ )' followed by farmer's traditional variety Kadri -6 recorded an average yield of (17.9 $\left.\mathrm{q} \mathrm{ha}^{-1}\right)$. HYV groundnut variety Dharani with proper nutrient management and plant protection measures gave $17.13 \%$ higher over farmer's practices. The technological and extension gap was $15.4 \mathrm{q}$ $\mathrm{ha}^{-1}$ and $37.0 \mathrm{q} \mathrm{ha}^{-1}$ respectively with technological index 41.6 percentage. The benefit cost ratio was 2.4 and 2.1 in case of Dharani and Kadri -6 respectively. Hence the existing local groundnut variety can be replaced by HYV Dharani since it fits well to the existing farming situation for higher productivity in rabi season. By conducting front line demonstrations on large scale in farmer's field, yield potential of groundnut can be enhanced largely which will increase the income level of farmers and improve the livelihood condition of the farming community. 


\section{Introduction}

Groundnut (Arachis hypogaea L.), is one of the most important crops among the different oilseed crops grown in India. Its oil is used for edible purpose also known as peanut, is a legume that ranks 6th among the oilseed crops and 13th among the food crops of the world. In addition to providing high quality edible oil (48-50\%), easily digestible protein (26-28\%), and nearly half of the 13 essential vitamins and 7 of the 20 essential minerals necessary for normal human growth and maintenance, it produces high quality fodder for livestock. Groundnut plays a significant role in the livelihoods of smallholder farmers. India is the largest producer of oilseeds in the world and the oilseed sector occupies an important position in the country's economy. The country accounts for 12-15 per cent of global oilseeds area, 6-7 per cent of vegetable oils production, and 9-10 per cent of the total edible oils consumption $(F A O, 2011)$. India imports about half of its domestic consumption needs of edible oils. The continuous increase in import of oilseeds crops specially groundnut and mustard occupies a prominent position in Indian oilseeds scenario.

Groundnut is an important oilseed crop of Odisha grown in both kharif and rabi season and cover an area of 247.69 ('000 ha) ha with production of 416.11 (000MT) and $1680 \mathrm{~kg}$ ha-1 productivity. The district Malkangiri has been considered as productively potential region of groundnut due to assured irrigation facilities, precise irrigation management and favorable soil and climate conditions. However, there is a wide gap between the Potential and the actual production realized by the farmers due to partial adoption of recommended package of practices by the growers. Based on farmers' reports, several constraints contribute to yield fluctuation on groundnut production, including: unreliable rainfall; lack of high yielding disease tolerant varieties; pests and diseases; low producer prices; poor agronomic practices; and lack of institutional support (Bucheyeki et al., 2008; Okoko et al., 1998). One of the major problems of groundnut production and processing is huge inefficiencies due to an uncertain production environment owing to rain fed cultivation, the low resource base of smallholder farmers and processors, and the low adoption rates of improved technology.

Technology gap i.e. poor knowledge about newly released crop production and protection technologies and their management practices in the farmers' fields is a major constraint in groundnut production. The production potential could be increased by adopting recommended scientific and sustainable management production practices with improved high yielding varieties and other critical inputs.

\section{Yield Gap in Production}

Yield potential (Yp) also called potential yield, is the yield of a crop variety when grown with water and nutrients no limiting and biotic stress effectively controlled (Evans, 1993, Van Ittersum and Rabbinge, 1997). Researchers acknowledge the presence of yield gaps between potential and farm level yields across ecologies, regions, and countries (FAO, 2004) and yield gaps could be attributed to factors such as: biophysical, socioeconomic, policy and/or institutional, technology transfer, and linkage to agricultural experts. These gaps could be differentiated into three categories.

\section{Gap I}

The gap between the theoretical yield and yield attained at experimental station- this serves as a guide in varietal breeding at research stations. 


\section{Gap II}

The gap between the attainable yield at experimental stations and the potential yield realized at the farm level- normally attributed to factors that are non-transferable.

\section{Gap III}

The gap between the potential farm yield and the actual yield realized by the farmersmainly attributed to management practices.

At the farm level, the most viable option is to narrow the gap between the potential and actual farm yields or Gap III. Nonetheless, this gap is not static. The yield gap enlarges with new technology development thus breeding of new groundnut varieties changes the yield potential. Hence, the actual groundnut yield at the farm level depends on management aspect that is associated with socioeconomic in addition to biophysical factors (Bindraban et al., 2000). The yield gap is viewed as differences between achievable yield and the actual yield under optimal management practices. Yields of crops must increase substantially over the coming decades to keep pace with global food demand driven by population and income growth. Quantifying food production capacity on every hectare of current farmland in a consistent and transparent manner is needed to inform decisions on policy, research, development and investment that aim to affect future crop yield and land use, and to inform on-ground action by local farmers through their knowledge networks.

Front line demonstration is one of the important tools for transfer of technology. Conducting cluster front line demonstrations on farmer's field help to identify the constraints and potential of the groundnut in specific area as well as it helps in improving the economic and social status of the farmers.
Font line demonstration is a concept of field demonstrations evolved by in Indian Council of Agriculture and Research (ICAR) during the inception of Technology Mission on Oilseed crops during mid-eighties. The field demonstrations conducted under close supervision of scientists of the National agricultural Research System is called front line demonstration because the technologies are demonstrated for the first time by the scientist themselves before being fed into the main extension system of the state department of agriculture (Venkatasubramanian et al., 2009). The main objective of front line demonstrations is to demonstrate newly released crop production technologies and its management practices in the farmers' field under different farming situations and at different agro-climatic regions. The newly and innovative technology having higher production potential under the specific cropping system can be popularized through front line demonstrations programme (Pokar, et al., 2014). Keeping the above point in view, the Cluster Front Line demonstration (CFLD) on groundnut using improved production technologies was conducted with the objective of showing the productive potentials of the integrated production technologies under actual farm situation. The present front line demonstration was carried out by Krishi Vigyan Kendra, Malkangiri, under the supervision of agricultural scientists and the seeds of high yielding variety Dharani and other critical inputs were provided to the farmers by KVK to find out yield gaps between farmers practices (FP) and Recommended Practices (RP) under CFLD programme.

The present investigation was under taken for assessing the performance and yield attributing parameters and economic of return of HYV groundnut variety Dharani in Malkangiri district of South Eastern Ghat Zone of Odisha in comparison with farmers 
cultivar (Kadri-6). The present study has been undertaken to evaluate the difference between demonstrated technologies vis-a-vis practices followed by the local farmers in Groundnut crop under actual farm situation.

\section{Materials and Methods}

The study was carried out in operational villages of Krishi Vigyan Kendra (KVK), Malkangiri during rabi season in the year 2019-20. The demonstrations were conducted in four different adopted villages MV-3, MV9 and MV-8 of Malkangiri block and Dhusuriguda of Khairiput block in cluster approach. The geographic location of the areas were Longitude- $81^{0} 75^{\prime} .333^{\prime}$ ' $\mathrm{E}$, Latitude- $18^{0}$ $06^{\prime} .278^{\prime} \mathrm{N}$. and Longitude $82^{0} 16^{\prime} .197^{\prime} \mathrm{E}$, Latitude- 18.303195N. 18 30', 319'”E.

Before conducting demonstration a list of eighty four farmers was prepared by conducting group meeting and specific skill training was imparted to the selected farmers regarding improved crop management aspects. Eight four numbers of front line demonstrations were conducted in four clusters. All the participating farmers were trained on various aspects of ground nut production technologies and recommended agronomic practices and certified seeds of groundnut variety Dharani were used for demonstration. The total area demonstrated was 40.0 ha and plot area of individual farmer was 0.2 to 0.4 ha. The soil of demonstration site was slightly acidic in reaction ( $\mathrm{pH}-5.0$ to 6.2) with sandy loam in texture and EC was 0.139 (dS $\mathrm{m}-1$ ). The available nitrogen, phosphorus and potassium was between 185192, 19-21.5, 105-120.00 (Kg ha-1) respectively and available Sulphur was 26 to $35(\mathrm{~kg} / \mathrm{ha})$ with medium level of $(0.4$ to $0.6 \%)$ Organic Carbon. The crop was sown in under irrigated condition in the second week of January with irrigation at critical stages of the crop. The crop was raised with recommended agronomic practices and harvested within 4th week of March up to 1st week of April.

Krishi Vigyan Kendra, Malkangiri conducted front line demonstration with following technologies in cluster approach and the technologies demonstrated were as follows: Popularization of high yielding Ground nut variety Dharani, Seed treatment with Vitavax power@2 $\mathrm{g} \mathrm{kg}^{-1}$ seed, Line sowing with, soil test based fertilizer application and use of Sulphur $20 \mathrm{~kg} \mathrm{ha}^{-1}$ along with need based plant protection measures for sucking pest and pod borers. The field was ploughed two times and planking was done after each ploughing, Prior to sowing seeds were treated with Vitavax power@2g kg seed per kg of seed, and sown in line with spacing $25 \times 10 \mathrm{~cm}$ and seed rate was $125 \mathrm{~kg}$ kernel per ha. Need based plant protection measures were taken, along with soil test based fertilizer application was done with fertilizer dose 20:40:40 kg. N: $\mathrm{P}_{2} \mathrm{O}_{5}: \quad \mathrm{K}_{2} \mathrm{O} \quad \mathrm{kg}$ ha $\quad$-1. $\quad$ Spraying of Thiomethoxam @6 gm/ 10 lit of water for sucking pest management, spraying of Triazophos + Deltamethrin @ $2.5 \mathrm{ml} / \mathrm{lit}$ for pod borer control was followed. The farmers' practices were maintained in case of local checks. The observations were recorded for various parameters of the crop. The field observations were taken from demonstration plot and farmers' plot as well. Parameters like, plant height $(\mathrm{cm})$ number of pods plant ${ }^{-1}, 100$ seed weight $(\mathrm{gm})$ and seed yield $(\mathrm{q} / \mathrm{ha})$ were recorded at maturity stage and the gross returns ( $\mathrm{Rs} \mathrm{ha}^{-1}$ ) was calculated on the basis of prevailing market price of the produce. The extension gap, technology gap, technology index along with $\mathrm{B}$ : $\mathrm{C}$ ratio was calculated and the data were statistically analyzed applying the statistical techniques. To estimate the technology gap, extension gap and technology index following formulae have been used. The data obtained from recommendation practices (RP) and famers practices (FP) were analyzed for evaluating extension gap, technological 
gap, technological index and benefit cost ratio (Samui et al., 2000) as given below. Finally the data were tabulated and analyzed by using percentage, mean, $\mathrm{SD}$, " $\mathrm{Z}$ test " and regression analysis was done to draw the inferences using the standard procedure given by (Cochran W. G., Cox G. M., 1977) and (Panse, V. G. and Sukhatme, P. V. 1985).

Technology gap $=\mathrm{Pi}($ Potential yield $)-\mathrm{Di}$ (Demonstration yield)

Extension gap $=$ Di $($ Demonstration Yield $)-\mathrm{Fi}$ (Farmers yield)

Technology index
Technology gap
$=$--------------- $\times 100$
Potential Yield

High yielding groundnut variety Dharani (TCGS 1043) with duration is 100-105 days was drought tolerant, withstands up to 35 days dry spell, uniform maturity, attractive pods, moderate stature, water use efficient, tolerant to stem and dry root rots was taken for demonstration (Radha Kumari C. and Sahadeva Reddy B. 2019). The average pod yield of Dharani variety is $3700 \mathrm{~kg} \mathrm{ha}^{-1}$, with shelling percentage $75 \%$ and oil content $50 \%$.

\section{Results and Discussion}

The results of the present study as well as relevant discussions have been presented under following sub heads.

\section{Differences between farmer's practices and Technology demonstrated}

The major differences were observed between demonstration package and farmer's practices are regarding recommended varieties, seed treatment, soil test based fertilizer application, method of integrated weed management and plant protection measures. The data of Table 1 showed that under the demonstrated plot only recommended high yielding variety, seed treatment and need based plant protection chemicals, herbicides were used by the farmers and all the other package and practices were timely performed by the farmer. It was also observed that farmers were unaware about balanced fertilizer application, seed treatment and use of micronutrient Sulphur for enhancing the oil content and weed management practices in groundnut. The findings are in corroborated with the findings of (Singh and Chaudhury, 1995), (Katare et al., 2011) and (Jat et al., 2011).

The data on crop growth parameters as reported in Table 2 indicated that the number of pods per plant in Dharani under demonstration was 22 as compared to 16 in case of Kadri-6, which was $37 \%$ higher. Among the two varieties Dharani achieved average plant height $24.9 \mathrm{~cm}$ followed by 21.8 $\mathrm{cm}$ in Kadri-6 in farmers practices. The parameters like more plant height and more number of pods per plant and seed weight were the attributing factors for higher yield in Variety Dhrani.

The result indicated that average pod yield of groundnut Var Dharani and Kadri-6 was 21.59 $\mathrm{q} \mathrm{ha}^{-1}$ and $17.9 \mathrm{q} \mathrm{ha}^{-1}$ respectively which was 17.13 percentages higher. The probable reason might due to genotype, more plant height and lesser incidence of root rot disease coupled with higher number of pods plant ${ }^{-1}$ resulting higher pod yield and concurrence with the findings of (Kumari and Reddy, 2019).

The calculated ' $Z$ ' value (7.89) was found to be significant. It was concluded that the yield of groundnut Var Dharani was significantly higher as compared to farmers' Variety Kadri6 under this demonstration. The results of this study were in line with the results of the study conducted by (Punithavathi M. et al., 2021). It may be observed from the table that all the 
independent variables explained for about 70.4 percent variation in pod yield of ground nut under demonstration. Further $\mathrm{F}$ test was observed to be significant at 0.05 level of probability. But on application of $t$ test of significance the coefficient of regression (bvalue) was found to be significant for parameter variables like no of pods per plant, 100 Kernel wt, and Haulm Yield. Hence it was concluded that higher number of pods plant ${ }^{-1}$ 100 kernel weight and biomass yield were the influencing factors for resulting higher pod yield in groundnut variety Dharani. The findings were in conformity to the observations reported by Kumari and Reddy (2019).

The technological and extension gap was 15.4 and $3.7 \mathrm{q}$ ha-1 respectively. Similarly, technological index was 41.6 percent. By conducting cluster front line demonstration with intervention practices of proven technologies in farmer's field, yield potential of groundnut can be enhanced to a great extent. The technology index showed the feasibility of the improved technology at the farmer's field. Such fluctuation in technology index during the study period may be attributed to the dissimilarity in soil fertility status, weather condition, non-availability of irrigation water at critical stages and insectpest attack. The present results were in agreement with earlier findings of (Singh and Chaudhury, 1995).

The economics and $\mathrm{B}: \mathrm{C}$ ratio of farmers practice and recommended practice has been presented in Table 7. Cost of cultivation under demonstration plot was higher than control plots because of additional application of nutrients. Keeping the prevailing local market price of groundnut as $4500.00\left(\mathrm{Rs} \mathrm{q}^{-1}\right)$ in the particular year the economic analysis was undertaken. The results on economic analysis of groundnut production revealed that the gross return and net return in case of recommended practice (RP) was higher than farmers practice. The results were in agreement with the findings of (Yogesh D et al., 2018)

The HYV variety groundnut Dharani recorded higher gross return Rs 97155 per ha, which was 29.0 percentage higher than farmers' practice and it was due to higher productivity of variety Dharani under demonstration. The maximum net returns with higher benefit-cost ratio (2.42) of groundnut cultivation during rabi season was obtained with groundnut cultivar 'Dharani'. Similar findings were reported by (Bhagavatha Priya et al., 2016).

From the Table 8 , it was revealed that in the district Malkangiri the productivity of groundnut was $23.11\left(\mathrm{q} \mathrm{ha}^{-1)}\right.$ as compare to state average productivity $17.87\left(\mathrm{q} \mathrm{ha}^{-1}\right)$ but there exists a gap between potential yield and farmers yield, which can be minimized by adoption of improved management practices.

It was revealed from the above Fig -I that productivity and production of ground nut in this district has been increased significantly also with area expansion from last five years. It was due to more extensive crop diversification from traditional crops to oil seed crops in upland and med land irrigated situation, use of HYV of ground nut with proper management practices adopted by the farmers and also they were getting remunerative price for their produce due to developed market linkage. 
Table.1 Comparison between farmer's practices and Technology demonstrated

\begin{tabular}{|c|c|c|c|}
\hline SI.No. & Particulars & Farmer's practice & Demonstrated Technology \\
\hline 1 & Variety & Kadri -6 & Dharani \\
\hline 1 & Seed rate & $100 \mathrm{~kg} \mathrm{ha}^{-1}$ & $125 \mathrm{~kg} \mathrm{ha}^{-1}$ \\
\hline 2 & Seed treatment & No seed treatment & Seed treatment with Vitavax power @ $2 \mathrm{~g} \mathrm{~kg}^{-1}$ seed \\
\hline 3 & $\begin{array}{l}\text { Method of } \\
\text { sowing }\end{array}$ & $\begin{array}{l}\text { Line sowing } \\
30 \times 20 \mathrm{~cm}\end{array}$ & Line sowing with spacing $25 \times 10 \mathrm{~cm}$ \\
\hline 4 & $\begin{array}{l}\text { Fertilizer } \\
\text { application }\end{array}$ & $\begin{array}{l}\text { Irrational use of } \\
\text { nitrogenous } \\
\text { fertilizer, no } \\
\text { Sulphur application }\end{array}$ & $\begin{array}{l}\text { Fertilizer dose NPK - 20:40:40 kg. N: } \mathrm{P}_{2} \mathrm{O}_{5}: \mathrm{K}_{2} \mathrm{O} \text { ha } \\
-1 \text {. Along with Sulphur @ } 20 \mathrm{~kg} \text { ha-1 }\end{array}$ \\
\hline 5 & $\begin{array}{l}\text { Plant protection } \\
\text { measure }\end{array}$ & $\begin{array}{l}\text { Use of Insecticide } \\
\text { like Dimethoate, } \\
\text { Imidacloprid and } \\
\text { Chloropyriphus }\end{array}$ & $\begin{array}{c}\text { Spraying of Thiomethoxam @ } 6 \mathrm{gm} / 10 \text { lit for } \\
\text { management of sucking pests, Spraying of } \\
\text { Triazophos + Deltamethrin @ } 2.5 \mathrm{ml} / \mathrm{lt} \text { for pest } \\
\text { management like red hairy caterpillar and gram pod } \\
\text { borer }\end{array}$ \\
\hline 6 & $\begin{array}{c}\text { Weed } \\
\text { management }\end{array}$ & $\begin{array}{l}\text { Manual weeding at } \\
25-30 \text { days }\end{array}$ & $\begin{array}{l}\text { Manual weeding at 25-30 DAS with post emergence } \\
\text { spray of Imazethapyr @ } 70 \mathrm{gm} \text { ai/ha }\end{array}$ \\
\hline
\end{tabular}

Table.2 Agronomical parameters of groundnut observed in farmers' field and demonstration field

\begin{tabular}{|c|c|c|c|c|c|}
\hline Variety & $\begin{array}{c}\text { Plant height at 90 } \\
\text { DAS (cm) }\end{array}$ & $\begin{array}{c}\text { Pods/plant } \\
(\mathbf{N o})\end{array}$ & $\begin{array}{c}\text { 100 kernel } \\
\text { weight }(\mathbf{g})\end{array}$ & $\begin{array}{c}\text { Pod yield } \\
\left(\mathbf{q} \mathbf{~ h a}^{-\mathbf{1}}\right)\end{array}$ & $\begin{array}{c}\text { Harvest } \\
\text { Index (HI) }\end{array}$ \\
\hline Kadri-6 & 21.8 & 16 & 42.6 & 17.9 & 52.3 \\
\hline Dharani & 24.9 & 22 & 54.6 & 21.6 & 56.4 \\
\hline
\end{tabular}

Table.3 Yield performance of groundnut under farmers practice and demonstration

\begin{tabular}{|c|c|c|c|c|c|c|c|c|c|c|}
\hline \multirow[t]{3}{*}{ Cluster } & \multirow[t]{3}{*}{$\begin{array}{l}\text { Area } \\
\text { in } \\
\text { ( ha) }\end{array}$} & \multirow[t]{3}{*}{$\begin{array}{l}\text { Number } \\
\text { of } \\
\text { Farmers }\end{array}$} & \multirow{3}{*}{$\begin{array}{c}\text { Existing } \\
\text { (Farmer's) } \\
\text { Yield } \\
\text { (q ha-1 ) }\end{array}$} & \multicolumn{3}{|c|}{$\begin{array}{l}\text { Demonstration } \\
\text { Yield Obtained } \\
\qquad\left(\mathbf{q} \mathbf{h a}^{-1}\right)\end{array}$} & \multirow{2}{*}{\multicolumn{4}{|c|}{$\begin{array}{c}\text { Cost Benefit Analysis under } \\
\text { Demonstration }\end{array}$}} \\
\hline & & & & \multirow[t]{2}{*}{ Max } & \multirow[t]{2}{*}{ Min } & \multirow[t]{2}{*}{ Avg } & & & & \\
\hline & & & & & & & $\begin{array}{l}\text { Gross } \\
\text { Cost } \\
(\mathbf{R s} \\
\left.\text { ha }^{-1}\right)\end{array}$ & $\begin{array}{c}\text { Gross } \\
\text { Return } \\
(\mathbf{R s} \\
\left.\mathbf{h a}^{-1}\right)\end{array}$ & $\begin{array}{c}\text { Net } \\
\text { Return } \\
(\text { Rs } \\
\left.\text { ha }^{-1}\right)\end{array}$ & $\begin{array}{c}\text { B:C } \\
\text { Ratio }\end{array}$ \\
\hline I & 13 & 26 & 17.3 & 21.8 & 18.2 & 20.46 & 41500 & 92070 & 50570 & 2.22 \\
\hline II & 10 & 25 & 17.7 & 23.1 & 19.3 & 21.6 & 41500 & 97200 & 55700 & 2.34 \\
\hline III & 12 & 23 & 18.5 & 23.9 & 20 & 22.5 & 43000 & 101250 & 58250 & 2.35 \\
\hline IV & 5 & 10 & 18.2 & 23.1 & 19.1 & 21.8 & 40200 & 98100 & 57900 & 2.44 \\
\hline \multicolumn{3}{|c|}{ Mean } & 17.92 & 22.97 & 19.15 & 21.59 & 41550 & 97155 & 55605 & 2.34 \\
\hline
\end{tabular}


Table.4 Variance analysis of yield of groundnut varieties under demonstrations

\begin{tabular}{|c|c|c|c|c|c|}
\hline \multirow[t]{2}{*}{ Yield } & \multirow[t]{2}{*}{$\begin{array}{c}\text { Kadri -6 } \\
\left(q \text { ha }^{-1}\right)\end{array}$} & \multicolumn{3}{|c|}{$\begin{array}{l}\text { Dharani } \\
\left(\mathbf{q} \mathbf{h a}^{-1}\right)\end{array}$} & \multirow[t]{2}{*}{ B:C Ratio } \\
\hline & & Max & Min & Avg & \\
\hline Mean & 17.92 & 22.97 & 19.15 & 21.59 & 2.34 \\
\hline $\operatorname{SEd}( \pm)$ & 0.27 & 0.43 & 0.37 & 0.42 & 0.04 \\
\hline SD & 0.53 & 0.86 & 0.791 & 0.85 & 0.09 \\
\hline Sample Variance & 0.28 & 0.75 & 0.55 & 0.72 & 0.008 \\
\hline
\end{tabular}

Table.5 Comparison of groundnut Varity Dharani under demonstration

\begin{tabular}{|c|c|c|c|c|c|c|}
\hline Treatment & $\begin{array}{c}\text { Mean Yield } \\
\left(\mathbf{q} \mathbf{h a}^{-1}\right)\end{array}$ & SD & CV\% & $\begin{array}{c}\text { \% increase } \\
\text { over FP }\end{array}$ & 'Z' Value & $p$ - value \\
\hline $\begin{array}{c}\text { Farmer's } \\
\text { practice (FP) }\end{array}$ & 17.92 & 0.53 & 2.9 & \multirow[t]{2}{*}{17.13} & \multirow[t]{2}{*}{$7.89 *$} & \multirow[t]{2}{*}{$(\mathrm{p}(\mathrm{x} \leq \mathrm{Z})=0.00$} \\
\hline $\begin{array}{c}\text { Recommended } \\
\text { practice }(\mathbf{R P})\end{array}$ & 21.59 & 0.85 & 3.9 & & & \\
\hline
\end{tabular}

(The test statistic $\mathrm{Z}$ equals to 7.89 , Indicates significance value at $\mathrm{p}=0.05$, critical value two tail $\mathrm{z}$ score $=1.96$ )

Table.6 Factors affecting pod yield in ground nut

\begin{tabular}{|c|c|c|c|c|c|}
\hline \multicolumn{2}{|c|}{ Regression co efficient } \\
\hline $\mathbf{S}$ S.no & $\begin{array}{c}\text { Independent } \\
\text { variables }\end{array}$ & Coefficients of partial regression (b- value ) & Standard Error & t value & F \\
\hline $\mathbf{1}$ & $\begin{array}{c}\text { Pant Ht ( } \\
\text { XI) }\end{array}$ & -0.018 & 0.046 & 0.392 & 46.990 \\
\hline $\mathbf{2}$ & $\begin{array}{c}\text { No of Pods } \\
\text { per } \\
\text { plant)(XII) }\end{array}$ & 0.321 & 0.044 & $7.209^{*}$ \\
\hline $\mathbf{3}$ & $\begin{array}{c}\text { 100 Kernel } \\
\text { wt (XIII) }\end{array}$ & 0.014 & 0.047 & $2.299^{*}$ \\
\hline $\mathbf{4}$ & $\begin{array}{c}\text { Haulm } \\
\text { Yield (XIV) }\end{array}$ & 0.159 & 0.027 & $6.003^{*}$ \\
\hline
\end{tabular}

R square value 0.704, Adj $\mathrm{R}^{2}$ value 0.689, Standard Error 0.734

Table.7 Technology gap, extension gap and technology index of groundnut var.Dharani under cluster frontline demonstration

\begin{tabular}{|c|c|c|c|c|}
\hline Variety & $\begin{array}{c}\text { Average } \\
\text { yield } \\
(\mathbf{q ~ h a}\end{array}$ & $\begin{array}{c}\text { Technology } \\
\text { gap } \\
\left(\mathbf{q} \mathbf{h a}^{-1}\right)\end{array}$ & $\begin{array}{c}\text { Extension } \\
\text { gap } \\
(\mathbf{q ~ h a}\end{array}$ & $\begin{array}{c}\text { Technology } \\
\text { Index }(\%)\end{array}$ \\
\hline Kadri-6 ( FP) & 17.9 & 15.4 & 3.7 & 41.6 \\
\hline Dharani ( RP) & 21.6 & & & \\
\hline
\end{tabular}


Table.8 Economics and benefit cost ratio comparison between Farmers practice and recommended practice

\begin{tabular}{|c|c|c|c|c|}
\hline Treatment & $\begin{array}{c}\text { Cost of cultivation } \\
\left(\mathbf{R s ~ h a}^{-\mathbf{1}}\right)\end{array}$ & $\begin{array}{c}\text { Gross Return } \\
\left(\mathbf{R s ~ h a}^{-\mathbf{1}}\right)\end{array}$ & $\begin{array}{c}\text { Net Return } \\
\left(\text { Rs ha }^{\mathbf{1}}\right)\end{array}$ & B:C ratio \\
\hline Farmer's practice (FP) & 32500 & 75285 & 42785 & 2.21 \\
\hline Recommended practice (RP) & 40000 & 97155 & 57115 & 2.42 \\
\hline
\end{tabular}

(Market price of ground nut pod was Rs 4500.00 per quintal)

Table.9 Area, production and productivity of groundnut in Malkangiri district in comparison with state Odisha

\begin{tabular}{|c|c|c|c|c|c|c|}
\hline \multirow[b]{2}{*}{ Crop } & \multicolumn{3}{|c|}{ Odisha } & \multicolumn{3}{|c|}{ Malkangiri } \\
\hline & $\begin{array}{c}\text { Area } \\
\text { ('000 ha) }\end{array}$ & $\begin{array}{l}\text { Production } \\
\text { ('000MTs) }\end{array}$ & $\begin{array}{c}\text { Productivity } \\
\left(\mathbf{q ~ h a}^{-1}\right)\end{array}$ & $\begin{array}{c}\text { Area } \\
\left(000^{\prime} h a\right)\end{array}$ & $\begin{array}{l}\text { Production } \\
\text { ('000MTs) }\end{array}$ & $\begin{array}{c}\text { Productivity } \\
\left(\mathbf{q} \mathbf{h a}^{-1}\right)\end{array}$ \\
\hline Groundnut & 267.68 & 478.33 & 17.87 & 19.34 & 44.68 & 23.11 \\
\hline
\end{tabular}

Table.10 Groundnut area in different blocks of Malkangiri district (Year 2020-21)

\begin{tabular}{|c|c|c|c|}
\hline Name of the block & Area(ha) & \% of total ground nut area & Rank \\
\hline Malkangiri & 1425.0 & 7.37 & III \\
\hline Korukonda & 6973.0 & 36.05 & II \\
\hline Mathili & 56.0 & 0.29 & V \\
\hline Kalimela & 9855.0 & 50.95 & I \\
\hline Podia & 936.0 & 4.84 & IV \\
\hline Khairput & 50.0 & 0.26 & VI \\
\hline K. Gumma & 47.0 & 0.24 & VII \\
\hline
\end{tabular}

(District Agriculture rabi strategy report 2020-21)

Fig.1 Trend Analysis of production and productivity in ground nut in Malkangiri

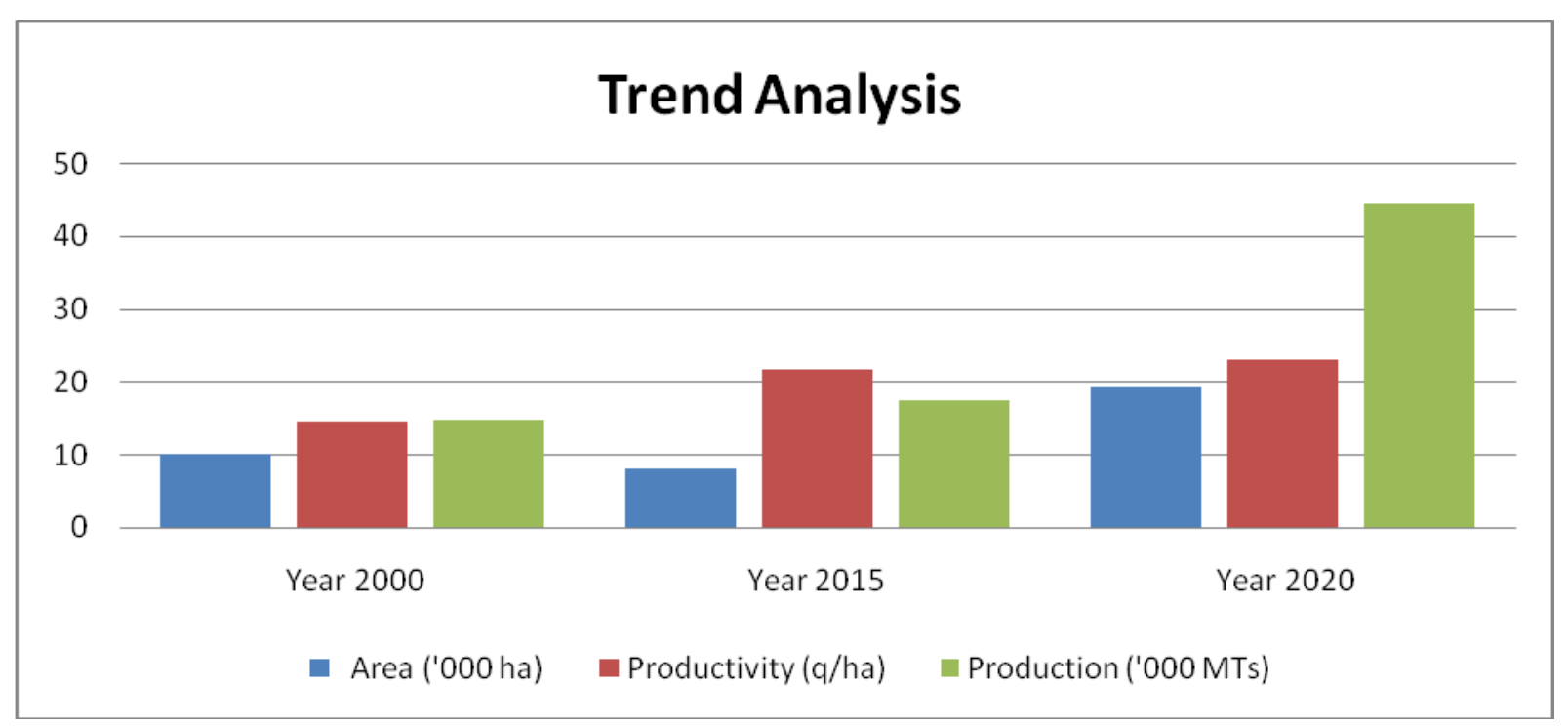


Fig.2 Groundnut area in different blocks of Malkangiri district (Year 2020-21)

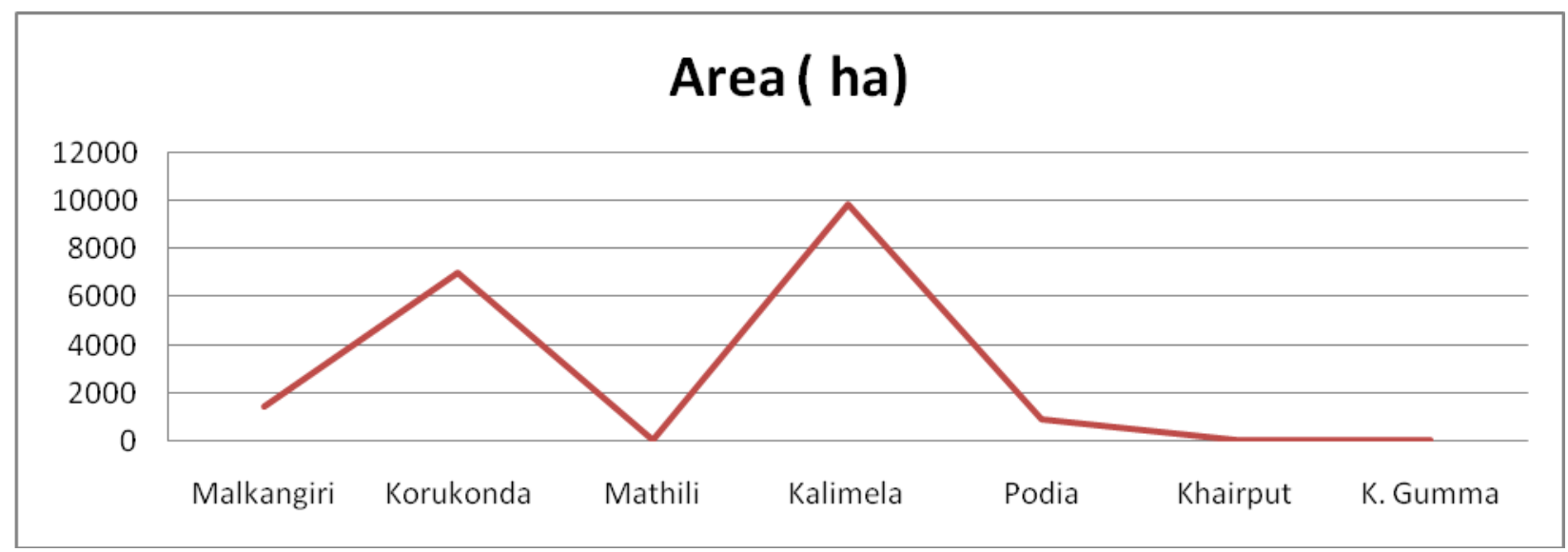

Total area covered in Malkangiri district under groundnut in the year 2020-21 in rabi season was 19342 ha as per the district agricultural statistics. Groundnut area is highest in Kalimela block and it was due to assured irrigation facility and suitable soil type for groundnut cultivation in this block, followed by Korukonda and Malkangiri block.

The principal reasons for lower productivity of groundnut in case of existing farmers practices in the district Malkangiri, were lack of knowledge among the farmers about cultivation of groundnut with modern technology, unawareness of improved varieties and improper fertilization, crop loss at the time of various stages of crop production and severe weed infestation in crop at critical stages. From the above findings it was revealed that groundnut variety Dharani recorded more number of pods per plant, higher pod yield, good withstand under drought condition and performed very well compared to Kadri-6. By adopting the scientific methods and technological practices of groundnut cultivation farmers can reduce the technological gap to a considerable extent thus leading to higher productivity of groundnut in the district. Yield improvement in groundnut under demonstration was due to combined effect of high yielding variety Dharani, balanced nutrients with Sulphur application and adoption of improved plant protection measures. It was concluded that the CFLD programme taking high yielding ground nut variety Dharani was a successful tool for enhancing the production and productivity of groundnut in the district. Farmers are convinced with variety Dharani, as the crop did not suffer from a dry spell of 18-22 days without rain. Thus, groundnut variety Dharani would be better option for cultivation during rabi season for Malkangiri district.

\section{Acknowledgement}

Authors are thankful to Odisha University of Agriculture and Technology, Bhubaneswar, 751003, Odisha and ICAR- ATARI, Kolkata.

\section{Ethical Approval}

This article does not contain any studies with human participants or animals performed by any of the authors.

\section{References}

Bhagavatha Priya T., Subramanyam D., Sumathi V., Naidu M. V. S. (2016) Growth Characters and Yield of Early Kharif Groundnut As Influenced By Varieties and Plant Populations, IOSR Journal of 
Agriculture and Veterinary Science,9(5), 81-83.

Bucheyeki, T. L., Shenkalwa, E. M., Mapunda, T. X. and Matata, L. W. (2008). On-farm evaluation of promising groundnut varieties for adaptation and adoption in Tanzania. African Journal of Agricultural Research, 3(8) : 531-536.

Choudhary B. N. (1999). Krishi Vigyan Kendra - A guide for KVK managers. Division of Agricultural Extension, ICAR, 73-78.

Cochran W. G., Cox G. M., (1977). Experimental Design, Asia publishing House, Kolkata, pp 95-132 and 142-181.

Evans, L. T. (1993). Crop Evolution, Adaptation, and Yield. Cambridge University Press, Cambridge, UK, 2(1).

Jat R. S., Meena H. N., Singh A. L., Surya Jaya N., Misra J. B. (2011). Weed management in groundnut (Arachis hypogaea L.) In India - A Review, Agricultural Reviews, 32, (3): 155-171.

Kalhapure A. H., Shete, B. T. and Bodake, P. S. (2013). Integration of chemical and cultural methods for weed management in groundnut. Indian Journal of Weed Science 45(2): 116-119.

Katare, S., Pandey, S. K., Mustafa, M. (2011). Yield gap analysis of Rapeseed-mustard through front line demonstration, Agriculture update, 6, (2): 5-7.

Kumari, C., Reddy, B. S., (2019). Evaluation of groundnut varieties for drought tolerance under imposed moisture stress conditions. Journal of Oilseeds Research 36(1): 24-29.

Panse, V. G. and Sukhatme, P. V. (1985) Statistical Methods for Agricultural
Workers. Indian Council of Agricultural Research Publication, 87-89.

Pokar, M. V., Javia. R. M, Sapar, G. K., Solanki, K. D. (2014). Adoption of improved groundnut production technology under front line demonstration, Agriculture update, 9(2) : 186-189.

Punithavathi, M., Vasanthakumar R. and Nethaji Mariappan V. (2021). International Journal of Bio-resource and Stress Management, Studies on Drought Tolerant and High Yielding Groundnut Varieties in Perambalur District, 12, Issue (1): 64-67

Radha Kumari C. and Sahadeva Reddy B. (2019) Evaluation of groundnut (Arachis hypogaea L.) varieties for drought tolerance under imposed moisture stress conditions, J. Oilseeds Res., 36(1) : 24-29.

Singh A. L. and Vidya Chaudhari. (1995). Source and mode of sulphur application on groundnut productivity. Journal of Plant Nutrition, Volume 18, (12) : 27392759.

Venkatasubramanian, V., Sajeev M. V., Singha A. K. (2010). Concept, Approaches and Mythologies for Technology Application and Transfer, ICT led Knowledge management in KVKs, The Zonal Project Directorate Zone -III, ICAR, Umiam, Meghalaya Chapter -IX. : 85-86.

Yogesh D. Pawar, Sachin H. Malve, F. K. Chaudhary, Umesh Dobariya, G. J. Patel, (2018).Yield gap analysis of groundnut through cluster front line demonstration under north Gujarat condition, Multilogic in science, VII. (XXV): 177-179.

\section{How to cite this article:}

Dash, S. R., S. P. Sangramsingh, B. K. Routray, A. K. Rai and Das, H. 2021. Performance and Yield Gap Analysis of Groundnut (Arachis hypogaea L.), Var Dharani through Cluster Front Line Demonstration in South Eastern Ghat Zone of Odisha. Int.J.Curr.Microbiol.App.Sci. 10(12): 43-53. doi: https://doi.org/10.20546/ijcmas.2021.1012.007 